\title{
Siblicide and Genetic Relatedness in Chicago, 1870-1930
}

\author{
Richard L. Michalski \\ Hollins University, Roanoke, Virginia \\ Daniel P. Russell \\ Todd K. Shackelford \\ Viviana A. Weekes-Shackelford \\ Florida Atlantic University, Davie
}

\begin{abstract}
Using a sample of siblicides committed in Chicago from 1870 through 1930, the authors tested two predictions heuristically guided by an evolutionary perspective. They predicted a greater proportion of siblicides of in-law siblings will be perpetrated by beatings, relative to the proportion of siblicides of full siblings. This difference did not reach statistical significance although it was in the predicted direction. They found, as predicted, that a significantly greater proportion of accidental deaths occurred with siblicides of full siblings relative to the proportion of siblicides of in-law siblings. Discussion addresses limitations of this research and the need for a national-level database that codes for the genetic relationship between the siblicide victim and offender to capitalize on greater statistical power.
\end{abstract}

Keywords: evolutionary psychology; genetic relatedness; siblicide; sibling-in-law

Siblicide - the killing of one sibling by another-is rare relative to other types of homicide. Underwood and Patch (1999) reported that of 65,390 total homicides coded in the Supplementary Homicide Reports (SHRs) of the FBI for the years 1993 through 1995, only $572(0.9 \%)$ were cases in which the offender and victim were siblings. Even including only intrafamilial homicides, siblicide is infrequent, with just 996 of 13,105 (7.6\%) coded as siblicide in the Uniform Crime Reports of the FBI for the years 1992 through 1996 (Underwood \& Patch, 1999). Although siblicide is rare relative to other homicides, violence between siblings is the most frequent form of intrafamilial nonlethal violence (Gelles \& Straus, 1988; Wiehe, 1997). The study of siblicide may provide insight into sibling relationships and nonlethal sibling conflict.

Authors' Note: We thank two anonymous reviewers for comments that improved the article. Please address correspondence to Richard L. Michalski, Hollins University, Department of Psychology, P.O. Box 9687, Roanoke, VA 24020; e-mail: rmichalski@hollins.edu 
An evolutionary perspective has been applied profitably to the study of homicide (see Buss, 2004; Daly \& Wilson, 1988), and to siblicide, in particular (Daly, Wilson, Salmon, Hiraiwa-Hasegawa, \& Hasegawa, 2001; Russell, Michalski, Shackelford, \& Weekes-Shackelford, 2007; Sulloway, 1996). Research generated from an evolutionary perspective suggests that differences may exist in the contexts and circumstances of siblicides of full siblings and siblings-in-law. ${ }^{1}$ This is because genetic relatedness may be an important moderator of conflict and homicide among family members, including siblings (Daly \& Wilson, 1988, 1998; Daly et al., 2001; Russell et al., 2007).

Russell et al. (2007) conducted the first investigation of siblicide as a function of the genetic relatedness between the victim and offender. Using the Chicago Homicide Database (CHD) for the years 1965 through 1994, the researchers found that a greater proportion of siblicides of full siblings were single-victim siblicides, relative to the proportion of siblicides of half-siblings and stepsiblings. Russell et al. also found that a greater proportion of siblicides of half-siblings and stepsiblings were perpetrated by beatings, relative to the proportion of siblicides of full siblings. The patterns of results were as predicted but did not reach statistical significance, perhaps due to relatively small sample sizes (few $n \mathrm{~s}>30$ ) and, therefore, inadequate statistical power (Cohen, 1988).

As a methodological extension of Russell et al. (2007), we include in the current study siblicides perpetrated by siblings-in-law to capitalize on greater statistical power offered by their inclusion and to yield more robust data distinguishing full, genetic siblings from other siblings. Siblings may be less likely to kill a full sibling, for example, because the evolutionary "fitness" costs associated with the death of a full sibling (with whom the perpetrator shares $50 \%$ of his or her genes) are higher than the fitness costs associated with the death of a sibling-in-law (with whom the perpetrator shares $0 \%$ of his or her genes). In addition, the psychological processes involved might be different for siblicides of siblings-in-law, relative to siblicides of full siblings.

Stepparents are more likely to use a more brutal method of killing their wards than genetic parents, which is arguably a manifestation of feelings of bitterness and resentment in stepparents not present to the same degree in genetic parents (Daly \& Wilson, 1994; Weekes-Shackelford \& Shackelford, 2004). In the current study, we define beating as a relatively brutal method of killing that includes the use of a blunt instrument or the use of one's hands, fists, or feet, following Daly and Wilson (1994; and see Russell et al., 2007; Weekes-Shackelford \& Shackelford, 2004). Parental investment in siblings-in-law may be viewed by a sibling as "wasted" investment, relative to investment in full siblings (who share more genes with the sibling). This "misdirected" investment may lead to feelings of jealousy and indignation toward siblings-in-law that are not present to the same degree toward full siblings. Following this logic, we offer the following prediction: 
Prediction 1: A greater proportion of siblicides of siblings-in-law will be perpetrated by beatings, relative to the proportion of siblicides of full siblings.

Because a greater evolutionary "fitness" cost is associated with the death of a full sibling relative to the death of a sibling-in-law, deliberate and intentional siblicides may be more frequent among siblings-in-law than among full siblings. Accidental siblicides (such as children playing with a loaded firearm when the weapon is suddenly discharged) between full siblings may be committed with greater regularity than among siblings-in-law, who may be more inclined toward purposeful and contemplated siblicides. We present the following prediction as a test of this logic:

Prediction 2: A greater proportion of accidental deaths will occur with siblicides of full siblings relative to the proportion of siblicides of siblings-in-law.

Predictions 1 and 2 are replications of predictions tested by Russell et al. (2007) using a different database and with a comparison of full-sibling siblicides and sibling-in-law siblicides. We use a citywide homicide database covering a 60 -year period to test these predictions.

\section{Method}

The Chicago Historical Homicide Project (CHHP) provides incident-level information on 11,018 homicides recorded in the murder analysis files of the Chicago Police Department for the years 1870 through 1930 (Bienen \& Rottinghaus, 2002). The CHHP is the only historical database known to us that codes for the genetic relationship between the siblicide victim and offender. We selected for analysis the 134 cases in which one sibling killed another sibling. Sixty four of these siblicides were committed by full siblings. A total of 70 siblicides were committed by persons other than full siblings. Two of these cases were coded as half-siblings, two cases as stepsiblings, and 66 cases as siblings-in-law. Only siblicides perpetrated by a sibling-in-law were included in the current study because of the lack of a meaningful sample size of siblicides by half-siblings and stepsiblings and to refine predictions specifically comparing full sibling and sibling-in-law siblicides. The overwhelming majority of siblicide offenders and victims were male $(96.3 \%$ of the offenders and $81.3 \%$ of the victims) and between age 12 and 44 years $(75.0 \%$ of the offenders and $81.6 \%$ of the victims). Following Daly and Wilson (1994), Weekes-Shackelford and Shackelford (2004), and Russell et al. (2007), we combined the weapon variable coded as "club or blunt instrument" with the weapon variable coded as "hands, fists, or feet" to form the category "beating." We tested the second prediction (regarding accidental siblicides) using the variable coded as "accidental" (as reported or inferred from the initial crime entry). Downloaded from http://hsx.sagepub.com at FLORIDA ATLANTIC UNIV on August 5, 2007
๑) 2007 SAGE Publications. All rights reserved. Not for commercial use or unauthorized distribution. 
Table 1

Demographic Information for Victim and Offenders of Siblicides Perpetrated by Full Siblings and by Siblings-in-Law

\begin{tabular}{|c|c|c|c|c|c|c|}
\hline \multirow[b]{2}{*}{ Sibling Relationship } & \multicolumn{3}{|c|}{ Victim } & \multicolumn{3}{|c|}{ Offender } \\
\hline & Male & Female & Overall & Male & Female & Overall \\
\hline \multicolumn{7}{|l|}{ Full siblings } \\
\hline Age in years $(S D)$ & 26.29 (12.09) & $13.40(18.52)$ & $25.09(13.13)$ & $14.75(7.40)$ & $6.50(3.54)$ & $13.57(7.50)$ \\
\hline$N$ & 49 & 5 & 54 & 12 & 2 & 14 \\
\hline \multicolumn{7}{|l|}{ Siblings-in-law } \\
\hline Age $(S D)$ & $32.36(8.33)$ & $28.36(10.54)$ & $31.36(9.00)$ & 27.00 & 21.00 & $24.00(4.24)$ \\
\hline$N$ & 42 & 14 & 56 & 1 & 1 & 2 \\
\hline
\end{tabular}

Note: $N$ s based on the subsample of cases with information on ages, not on the total sample of siblicides.

\section{Results}

See Table 1 for demographic information on the siblicides in the CHHP. The mean age of full-sibling victims was 25.1 years $(S D=13.1$ years $)$, and the mean age of sibling-in-law victims was 31.4 years $(S D=9.0$ years $)$. The mean age of full-sibling siblicide offenders was 13.6 years $(S D=7.5$ years), and the mean age of sibling-in-law offenders was 24.0 years $(S D=4.2$ years). The means for offender ages were based on very few cases because of missing values. These means, therefore, should be interpreted cautiously. Sixty two (96.9\%) of the full-sibling offenders were male and $67(95.7 \%)$ of the offenders in siblings-in-law siblicides were male. Fifty seven $(89.1 \%)$ of the full-sibling victims were male and $52(74.3 \%)$ of the victims in siblings-in-law siblicides were male.

Prediction 1 stated that a greater proportion of siblicides of siblings-in-law will be perpetrated by beatings, relative to the proportion of siblicides of full siblings. Three $(4.5 \%)$ of the siblicides committed by siblings-in-law were coded as beatings, compared to two $(3.1 \%)$ of the siblicides committed by full siblings. This difference was in the predicted direction but did not reach statistical significance, $\chi^{2}(1, N=130)=$ $.18, p>.05$. Prediction 1 , therefore, was not statistically supported. Two exemplary case descriptions of siblicides perpetrated by brothers-in-law appear below:

Kelly, David, shot dead, 329 Center St., by Charles Foster, his brother in law, whom he assaulted with a club. Foster was arrested and held by Coroner's Jury July 17. Acquitted by Jury in C.C. (Judge Neeley) Nov. 21, 1900. 40th Prect. Case Number 1180; July 16, 1900.

Sharples, Beatrice - Age 21 - Strangled to death in her home by her brother-in-law, Thos. Catherwood, who robbed her. On 11/23 Catherwood was held by the Coroner. 21 Dist. 1/20/22 to Joliet Pen for life - Fitch. Case number 7010; November 1, 1921. 
Prediction 2 stated that a greater proportion of accidental deaths will occur with siblicides of full siblings relative to the proportion of siblicides of siblings-in-law. Seventeen $(26.6 \%)$ of the siblicides committed by full siblings were coded as accidental deaths, whereas two (2.9\%) of the siblicides committed by siblings-in-law were coded as accidental deaths. This difference was in the predicted direction and did reach statistical significance, $\chi^{2}(1, N=130)=14.42, p<.001$. Prediction 2 , therefore, was supported. Two exemplary case descriptions of accidental siblicides appear below:

Lundstrom, Franz. 7 ys. old. Shot dead at home 2190 W. North Av. by his 11 yr. old brother, Ranzor. They were playing with a shot gun. 37 pct. Exonerated by coroner's jury. Case number 1380; November 26, 1907.

Hofsia, Maymie - Age 15 - Accidentally shot to death in kitchen of her home, 1733 @W. 106th Place, when her brother, William, dropped a revolver which he was cleaning. Revolver discharged upon striking the floor. William was exonerated by the Coroner. 10th Pct. Case number 6161; January 24, 1921.

\section{Discussion}

Guided heuristically by an evolutionary perspective, we tested two predictions about siblicides, using a city-level Chicago database of homicides committed during the years 1870 through 1930 . We found that a nonsignificantly greater proportion of siblicides of siblings-in-law were perpetrated by beatings relative to the proportion of siblicides of full siblings. We found that a significantly greater proportion of accidental deaths occur among siblicides of full siblings relative to the proportion of siblicides of siblings-in-law. The greater proportion of accidental deaths among fullsibling siblicides relative to the proportion of accidental deaths among sibling-in-law siblicides may be interpreted to reflect a lesser degree of rage or resentment present between full siblings.

The current study has several limitations. Similar to the results reported by Russell et al. (2007), the failure of the first prediction to reach statistical significance might be attributable to limited statistical power (Cohen, 1988). A clear problem of tests of the current predictions is the lack of a large, national-level homicide database that codes for the genetic relationship between siblicide victim and offender. In the absence of such a database, analyses comparing full siblings to siblings-in-law are limited to small databases that do have such codes. The CHHP does code for this relationship but is not without limitations. One limitation of the CHHP is that, for the majority of cases, the ages of the siblicide perpetrator and victim are not coded.

Despite these limitations, the current research offers several small but notable contributions to the literature on siblicide. The current research provides a replication and extension of the first investigation of siblicide as a function of the genetic 
relatedness between the victim and offender, conducted by Russell et al. (2007). The current research drew from a database of more than 11,000 homicides committed in Chicago during the years 1870 through 1930 to test predictions about the contexts and circumstances of siblicide. The results might be interpreted conservatively as providing preliminary qualitative evidence of the potential value of differentiating genetic relationship in siblicide research (see Farr, 2002, for a recent argument regarding the value of small-sample, qualitative research). The patterns of results of the current research and of Russell et al. (2007) provide qualitative (and limited quantitative) support for the two predictions tested using data for Chicago siblicides occurring over a century, suggesting that these patterns of siblicides may not be unique to a specific or recent time period.

\section{Note}

1. Analyses of siblicides also reveal birth-order patterns indicative of sibling rivalry predicted from an evolutionary perspective. Although not the focus of this article, other researchers (see Daly, Wilson, Salmon, Hiraiwa-Hasegawa, \& Hasegawa, 2001) found that older siblings are more likely to be perpetrators of siblicides early in life because of the jealousy of parental channeling of resources toward a younger sibling. In later life, younger siblings become more likely to be perpetrators of siblicides than older siblings because of an opportunity to secure resources (e.g., inheritance) that might otherwise be left to favored older siblings.

\section{References}

Bienen, L. B., \& Rottinghaus, B. (2002). Learning from the past, living in the present: Understanding homicide in Chicago, 1870-1930. Journal of Criminal Law \& Criminology, 92, 437-554.

Buss, D. M. (2004). Evolutionary psychology. Boston: Allyn \& Bacon.

Cohen, J. (1988). Statistical power analysis for the behavioral sciences (2nd ed.). Hillsdale, NJ: Lawrence Erlbaum.

Daly, M., \& Wilson, M. (1988). Homicide. Hawthorne, NY: Aldine de Gruyter.

Daly, M., \& Wilson, M. I. (1994). Some differential attributes of lethal assaults on small children by stepfathers versus genetic fathers. Ethology and Sociobiology, 15, 207-217.

Daly, M., \& Wilson, M. (1998). The truth about Cinderella. London: Weidenfeld \& Nicolson.

Daly, M., Wilson, M., Salmon, C. A., Hiraiwa-Hasegawa, M., \& Hasegawa, T. (2001). Siblicide and seniority. Homicide Studies, 5, 30-45.

Farr, K. A. (2002). Battered women who were "being killed and survived it": Straight talk from survivors. Violence and Victims, 17, 267-281.

Gelles, R., \& Straus, M. (1988). Intimate violence. New York: Simon \& Schuster.

Russell, D. P., Michalski, R. L., Shackelford, T. K., \& Weekes-Shackelford, V. A. (2007). A preliminary investigation of siblicide as a function of genetic relatedness. Journal of Forensic Sciences, 52, 738-739.

Sulloway, F. J. (1996). Born to rebel. New York: Pantheon.

Underwood, R. C., \& Patch, P. C. (1999). Siblicide: A descriptive analysis of sibling homicide. Homicide Studies, 3, 333-348.

Weekes-Shackelford, V. A., \& Shackelford, T. K. (2004). Methods of filicide: Stepparents and genetic parents kill differently. Violence and Victims, 19, 75-81.

Wiehe, V. R. (1997). Sibling abuse. Thousand Oaks, CA: Sage Publications. Downloaded from http://hsx.sagepub.com at FLORIDA ATLANTIC UNIV on August 5, 2007
๑) 2007 SAGE Publications. All rights reserved. Not for commercial use or unauthorized distribution. 
Richard L. Michalski received his $\mathrm{PhD}$ in psychology from Florida Atlantic University in 2005 . He is currently an assistant professor of psychology at Hollins University in Roanoke, VA. His research interests include family relationships and romantic relationships.

Daniel P. Russell received his BA in psychology from Florida Atlantic University in 2003. He is currently a doctoral student in clinical psychology at Spalding University in Louisville, KY. His research interests include psychological trauma and suicidology.

Todd K. Shackelford received his PhD in psychology from the University of Texas at Austin in 1997. He is currently a professor of psychology at Florida Atlantic University and chair of the Evolutionary Psychology Area. His research interests include conflict between the sexes, especially sexual conflict.

Viviana A. Weekes-Shackelford received her MA in psychology in 2003 and is currently a PhD candidate at Florida Atlantic University. Her research interests focus on within-family conflict over the lifespan from an evolutionary psychological perspective. 